\title{
Breast Cancer in Argentina: Analysis from a Collaborative Group for the Study of Female Breast Cancer
}

\begin{abstract}
Roberto P. Meiss Kress MD Path ${ }^{1,2^{*}}$, Roberto Chuit MD PhD², Jorge E. Novelli MD PhD ${ }^{3}$, Eduardo Abalo MD PhD ${ }^{3}$, Antonio Lorusso MD PhD Francisco E. Gago MD PhD ${ }^{3}$, Néstor C. Garello MD PhD ${ }^{3}$, Juan C. Staringer MD $^{3}$, René A. del Castillo, MD PhD ${ }^{3}$, Paola Spuri MD ${ }^{3}$, Susana Morales $\mathrm{MD}^{3}$, Soledad del Castillo $\mathrm{MD}^{3}$, Andrés del Castillo $\mathrm{MD}^{3}$, Magaly Pereyra Cousiño $\mathrm{MD}^{3}$, Alejandro J. Di Sibio MD ${ }^{3}$, Raúl J. Schwam

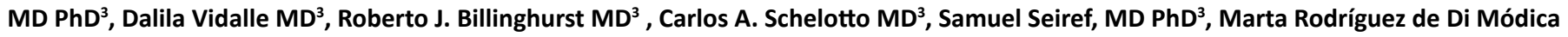
$M D^{3}$, María C. Robles $M D^{3}$, Fernando Martínez Corti $M^{3}$, Francisco von Stecher $M^{3}$, Jorge Sarrouf $M^{3}$, José A. Gómez MD $^{3}$, Graciela J.

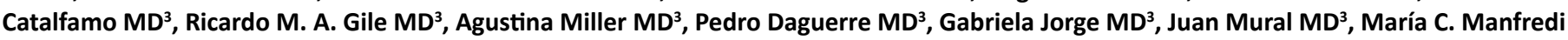
$M^{3}$, David O. Sigalevich $\mathrm{MD}^{3}$, Rafael Iñigo $\mathrm{MD}^{3}$, Stella Maris Raya MD PhD', Andrés Gómez Henson $\mathrm{MD}^{3}$, Karina Pesce MD PhD ${ }^{3}$, Cinthia E. Velázquez Andretta $\mathrm{MD}^{3}$, Guillermina P. Eidenson $\mathrm{MD}^{3}$, Leticia Ramos $\mathrm{MD}^{3}$, Pedro R. Crosa $\mathrm{MD}^{3}$, Federico L. Bianchi MD, Marta Martínez $M D^{3}$, Mariela Kugler $M^{3}$, Rubén Márquez Ruiz $M^{3}$, Sandra P. Rodas $M^{3}$, Roberto O. Virginio $\mathrm{MD}^{3}$, Romina Ciucci MD ${ }^{3}$, Rodolfo A. Righetti

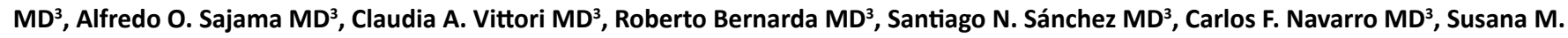
Sosa $\mathrm{MD}^{3}$, Nidia Real $\mathrm{MD}^{3}$, Javier I. J. Orozco $\mathrm{MD}^{3}$, Juan P. Begue $\mathrm{MD}^{3}$, Eugenio Villarroel $\mathrm{MD}^{3}$, Marcelo Schnitman Giacinti $\mathrm{MD}^{3}$, Katerine Torrez Monrroy $\mathrm{MD}^{3}$, Emiliano G. Peláez $\mathrm{MD}^{3}$, Alejandra C. Tissieres $\mathrm{MD}^{3}$, Orlando Á. Forestieri MD PhD ${ }^{3}$, Gustavo Wagner MD³ , Francisco N. Sosa $\mathrm{MD}^{3}$, Gustavo Olivera $\mathrm{MD}^{3}$, Lorenzo Medici $\mathrm{MD}^{3}$, Martín A. Vélez $\mathrm{MD}^{3}$ and Federico A. Coló MD

${ }^{1}$ Instituto de Estudios Oncológicos, Academia Nacional de Medicina, Buenos Aires, Argentina

${ }^{2}$ Instituto de Investigaciones Epidemiológicas, Academia Nacional de Medicina, Buenos Aires, Argentina

${ }^{3}$ Collaborative Group for the Study of Female Breast Cancer in Argentina, Buenos Aires, Argentina
\end{abstract}

\begin{abstract}
*Corresponding author: Roberto Pablo Meiss Kress, Instituto de Estudios Oncológicos, Academia Nacional de Medicina. Pacheco de Melo 3081, Buenos Aires, Argentina. C1425ADN; Tel: 54-11-4805-6461/5759, ext. 254; Fax: 54-11-4805-8176; E mail: rpmeiss@gmail.com

Article Type: Research, Submission Date: 13 January 2016, Accepted Date: 10 February 2016, Published Date: 10 February 2016.

Citation: Roberto P. Meiss Kress MD Path, Roberto Chuit MD PhD, Jorge E. Novelli MD PhD, Eduardo Abalo MD PhD, Antonio Lorusso MD PhD, et al. (2016) Breast Cancer in Argentina: Analysis from a Collaborative Group for the Study of Female Breast Cancer. J Can Epi Treat 1(2): 5-16. doi: https://doi.org/10.24218/jcet.2016.10.

Copyright: (C) 2016 Roberto P. Meiss Kress MD Path, et al. This is an open-access article distributed under the terms of the Creative Commons Attribution License, which permits unrestricted use, distribution, and reproduction in any medium, provided the original author and source are credited.
\end{abstract}

\begin{abstract}
Background: Breast Cancer (BC) is the most commonly diagnosed cancer amongst women worldwide with estimated incidence rate of 43, 1 per 100,000 and also in Argentine. With an estimated incidence rate of 71, 2 per 100,000 in 2012 our country is among the two ones with the high incidence in all Latin-America where the estimated incidence rate for $\mathrm{BC}$ is 47 , 2 per 100,000 .
\end{abstract}

Purpose: To describe the clinical and epidemiological characteristics of presentation of female $\mathrm{BC}$ in an attempt to explain the high incidence for $\mathrm{BC}$ despite the geographical location of the country, South America, a "less developed region" and with a "medium human development level" according to WB classification.

Methods: The Collaborative Group for the Study of Female Breast Cancer in Argentine (www.cancerdemama2012.org.ar) a consortium of 64 physicians from 75, public (26) and private (49), health services, reported 1732 case patients studied during the years 2012-2013. The following parameters were recorded: a) demographic; b) biological and c) pathological.

Results: a) Median age of 59 years (range: $23-92) ; 24,2 \%$ with university studies; 79, $1 \%$ with some kind of health coverage. b) Median age of menarche 13 years (range 9-21);menopause present in $72,3 \%$ of patients; nulliparous $19,1 \%$; median age at first full-term pregnancy of 24 (range 14-46); personal antecedent of breast cancer in $9,8 \%$ and familial in $27.9 \%$. c) $30.7 \%$ tumors under $2 \mathrm{~cm}$ of diameter; $3.0 \%$ of bilateral synchronous forms; $80.9 \%$ of infiltrating forms with predominance of ductal histological types; $7,5 \%$ triple-positive and $10 \%$ triple-negative molecular profile; clinical TNM: stage $0,7,2 \%$; I, 34,8\% ; IIa , 22,3\%; IIb, 11,8\%; IIIa, 8,3\%; IIIb, 3,5;IIIc , 2,9\% and IV. 2,9\%.

Conclusion: Taking into account the main risk factors and clinicpathologic features this population shows a "western" profile similar to that observed in developed countries and different from that observed in the rest of Latin American countries. This different profile for the geographic region and the development level of the country could be due to a genetic background of the population with a strong European influences, mainly in the last century.

\section{Introduction}

Breast Cancer (BC) is the most commonly diagnosed cancer amongst women worldwide with an estimated age-standardized rate (ASR) incidence, all ages, of 43, 1 per 100,000 according to the data from Globocan 2012 [1]. According to the same source of data the incidence of $\mathrm{BC}$ rates vary between the different geographic regions. Thus we have rates ranging from 29, 1 per 100,000 in Asia and 36,2 per 100,000 in Africa to 80,3 per 100,000 within the European Union and 85,8 per 100,000 in Australia / New Zealand; furthermore, there is wide variation in incidence rates of $\mathrm{BC}$ within the regions mentioned. 
Citation: Roberto P. Meiss Kress MD Path, Roberto Chuit MD PhD, Jorge E. Novelli MD PhD, Eduardo Abalo MD PhD, Antonio Lorusso MD PhD, et al. (2016) Breast Cancer in Argentina: Analysis from a Collaborative Group for the Study of Female Breast Cancer. J Can Epi Treat 1(2): 5-16. doi: https://doi.org/10.24218/jcet.2016.10.

The incidence of $\mathrm{BC}$ in America has two clearly defined situations. The northern region of the continent, Canada and USA, show incidence rates of 79,8 per 100,000 and 92,9 per 100,000 respectively. The rest of the continent has been added for their study under the name Latin America / Caribbean, with an incidence rate for $\mathrm{BC}$ of 47,2 per 100,000. Within this region there are differences in the incidence rates among the Caribbean area with 46,1 per 100,000 , Central America with 32,8 per 100,000 and South America with 52,1 per 100,000 [1,2]. Incidence rates for BC increased in all Latin America countries for the period 1980-2010 [3].

According to the World Bank [4], Argentina, situated in South America, belongs both to the "Less developed regions" and to the "Medium human development" group of countries where BC's estimated incidences are of 31, $3 \times 100,000$ and 26, 5x100, 000 respectively [1]. Despite these two categories and its geographic location Argentina is strikingly present among the countries with a high incidence rate for $\mathrm{BC}(71,2$ per 100,000). This incidence rate is near 1, 4 fold higher considering its geographical location and between 2, 3 and 2, 7 fold higher when considering their levels of development. The average incidence rate of $\mathrm{BC}$ in the five bordering countries is 45,4 per 100,000 (range, 19, 2-69, 8), 1,5 fold lower than the one indicated for Argentina [1]. Demographic, hereditary, economic, cultural, environmental, and lifestyle risk factors may account for this high BC incidence rate.

The Collaborative Group studied during the years 2012-2013 newly diagnosed female BC in Argentina to describe in detail the clinical and epidemiological characteristics of this cancer in an attempt to explain the high incidence rates observed above all estimated rates for this country.

\section{Material and methods}

The "Collaborative Group for the Study of Female Breast Cancer in Argentine" (PROYCAM 2012) is a multi-center prospective cohort study specifically designed to investigate the features of the breast cancer in Argentine women.

The present study was conducted between 1 January 2012 and 31 December 2013. A consortium of 64 physicians from 75, public (26) and private (49), health services reported 1732 case patients. Case definition was female cases of BC with a histologically confirmed laboratory diagnosis. Techniques and instruments of data collection: data were collected in two structured forms that appear in the on-line system (www.cancerdemama2012.org.ar). The first (Figure 1), self-administered character, is filled by the patient where she reports on age at diagnosis, level of education, health coverage, body mass index (BMI), menstrual history [age at menarche and menopause, exogenous hormone consumption and years of usage: OC and hormone replacement therapy (HRT)], reproductive history: number of full-term pregnancies, age at first full-term pregnancy, abortions, breastfeeding (practice and duration); the following information was also requested: personal non-cancer and cancer breast pathology history, a family history of breast cancer (limited to first and second-degree relatives only) and non-breast cancer. The second (Figure 2), an online form, was completed by the physician who reported the following data: clinical characteristics of tumor (localization, size), nodal involvement (presence, localization and number), distal metastasis (presence and site) and TNM clinical staging following Breast Cancer Staging, AJCC [5]. Data on histological types following the WHO Classification of Tumours of the Breast [6] and grade diagnosis, hormonal receptors status, Her2-neu overexpression, ki 67 and CK-5-6 immunohistochemistry studies, sentinel node study and pathological TNM were also collected. Diagnostic methods employed were also recorded. Population data was obtained from the National Office of Population Census (INDEC) [7]. Information and ethical considerations repairs: the project includes the principles contained in the Declaration of Helsinki, the National Law 25326 of Habeas Data Personal Data Protection and the National Patient Rights Act 26529 in its relationship with the professionals and health institutions. All patients signed a written informed consent (Figure 3).

\section{Results}

\section{Data collection}

Our analysis included 1732 patients with newly histologically confirmed breast cancer diagnosed and reported during the years 2012 and 2013. Argentina comprises 24 administrative units, 23 provinces and the city of Buenos Aires, capital of the country, a unit separated from the province of Buenos Aires. Seventy-four physicians, from 75 regional health services, both public (26) and private (49), reported throughout the country (18 provinces out of 24).

\section{Demographic characteristics}

Data on age of patients was available in 1710 cases $(99,2 \%)$. The average age is 59 years; the median, 59 years; the mode, 51 years; with a standard deviation of, 14 years and a range between a minimum of 23 years to a maximum of 92 years. The highest percentages of cases are concentrated in the age-group of 50-54 years $(12,3 \%)$. Uncommon below 30 years $(1,1 \%)$, BC doubles the cases in 30-34 years old women $(2,1 \%)$, keeping this rate of increase in group 35-39 years-olds (5,3\%) and in the 40 to 44 age group $(8,5 \%)$. Up until this age group the increase of cases is almost constant, every five-year periods; afterwards the trend tends to stabilize between the 45-49 and the 65-69 age groups. On considering the two ages taken as the lower age for mammography screening schemes, i.e. 40 and 50 years old $[8,9]$, we have a total of $17.0 \%$ of patients under 40 and $27.1 \%$ of patients below the 50 years old. A 15, 9\% of the patients are 74 years old or more at age of diagnosis (Table 1).

As for of health coverage systems for patients (data available in $96,7 \%$ of patients) union-organized health insurance prevails $(60,2 \%)$ with a lower incidence of uninsured patients $(17,6 \%)$ covered by the public health system. The subsectors of mutual health societies and private prepaid companies represent 2, 3\% and $17,6 \%$ of the cases, respectively (Table 1 ).

The education level, data available in $96,7 \%$ of the cases, shows that a relative significant number of cases has failed to complete their primary education (9,6\%); adding full primary education $(17,2 \%)$ and incomplete secondary education $(13,1 \%)$ makes a total of $39,9 \%$ of patients. A total of $52,2 \%$ of the patients have a high school degree or higher education; completed university studies were achieved by $24 \%$ of patients (Table 1 ).

\section{Gynecological and reproductive history}

Age at menarche in patients, data available in $94,6 \%$ of patients, 
Citation: Roberto P. Meiss Kress MD Path, Roberto Chuit MD PhD, Jorge E. Novelli MD PhD, Eduardo Abalo MD PhD, Antonio Lorusso MD PhD, et al. (2016) Breast Cancer in Argentina: Analysis from a Collaborative Group for the Study of Female Breast Cancer. J Can Epi Treat 1(2): 5-16. doi: https://doi.org/10.24218/jcet.2016.10.

\section{COLLABORATIVE GROUP FOR THE STUDY OF FEMALE BREAST CANCER IN ARGENTINA}

Last name:

First name:

Date of birth:_/_l__ (dd/mm/yyyy)

1- DEMOGRAPHICS DATA.

1.1. Place of birth:

Country State City Postal Code

1.2. Permanent address: Country State City Postal Code

\section{SOCIAL DATA}

2.1. Medical coverage: Social security Prepaid Mutual health society's Public health 2.2. Education (maximum level attained):

None Primary uncompleted primary completed Secondary uncompleted Secondary completed Tertiary/University uncompleted Tertiary/University uncompleted

\section{HEALTH HISTORY}

3.1. Do you perform gynecological check annually? Yes/ No 3.2. Month and year of the last gynecological control: Month/Year 3.3. Have you performed breast clinical examination or mammography on that occasion? Yes/ No

3.4. Does the patient know the technique of breast self-examination? Yes/ No 3.4.1. Does the practice? Yes/ No

3.5. How old were you when you started to menstruate? years 3.6. Did you use any oral contraceptive? Yes / No

3.6.1. How long? 3.7. Have you ever been pregnant? Yes/ No 3 .7.1. Age at first pregnancy years

3.7.2. How many children born alive? 3.7.3. Old when first child (living or dead) was born years

3.7.4. Indicate the months that you were breast-feeding each child

\begin{tabular}{|l|l|l|l|l|l|l|}
\hline Feeding time & Child 1 & Child 2 & Child 3 & Child 4 & Child 5 & Child 6 \\
\hline Any & & & & & & \\
\hline Less 3 months & & & & & & \\
\hline $3-6$ months & & & & & & \\
\hline 7-12 months & & & & & & \\
\hline More than 12 months & & & & & & \\
\hline
\end{tabular}

3.7.5. Have you ever had interrupted pregnancies? Yes/ No 3.7.5.1. How many?

3.8. Are you still having periods? Yes/ No 3.8.1. How old were you on your last period? years

3.9. Have you ever been indicated hormonal replacement therapy? Yes/ No 3.9.1. How long? years

\section{4- CONSUMPTIONS}

4.1. Have you smoked or smoke cigarettes, cigars? Yes/ No

4.2. Do you drink alcohol regularly? Yes/ No

\section{BODY CONDITION}

5.1. Current weight in kg: Current height in $\mathrm{cm}$ : 5.2. Did you have overweight, out of pregnancy? Yes/ No

5.2.1. What was your maximum weight? Weight in $\mathrm{kg}$ Age

\section{PERSONAL HISTORY OF BREAST PATHOLOGY /NON-BREAST CANCER}

6.1. Do you have a history of? : 6.1.1. Oophorectomy: Yes/ No 6.1.2. Mastopathy: Yes/ No 6.1.3. Atypical hyperplasia: Yes/ No 6.1.4. Carcinoma in situ: Yes/ No 6.1.5. Breast cancer: Yes/ No

6.1.6. Other cancer: Yes/ No 6.1.6.1. Uterine cervix Colon and rectum Lung Prostate Ovary Other (specify)

\section{FAMILY HISTORY}

7.1. Does it present a family history of breast cancer?: Yes/ No 7.1.1. Degree of kinship: Mother Sister Aunt and/or Cousin Daughter 7.2. Does it present family history of non-breast cancer? Yes/No 7.2.1. Prostate Lung Colon and rectum Ovary Pancreas Other 7.2.2. Degree of kinship: Father/mother brother/sister Uncle / aunt Cousins

Figure 1: Collaborative Group for The Study Of Female Breast Cancer In Argentina. Patients Self-Administered Questionnaire 
Citation: Roberto P. Meiss Kress MD Path, Roberto Chuit MD PhD, Jorge E. Novelli MD PhD, Eduardo Abalo MD PhD, Antonio Lorusso MD PhD, et al. (2016) Breast Cancer in Argentina: Analysis from a Collaborative Group for the Study of Female Breast Cancer. J Can Epi Treat 1(2): 5-16. doi: https://doi.org/10.24218/jcet.2016.10.

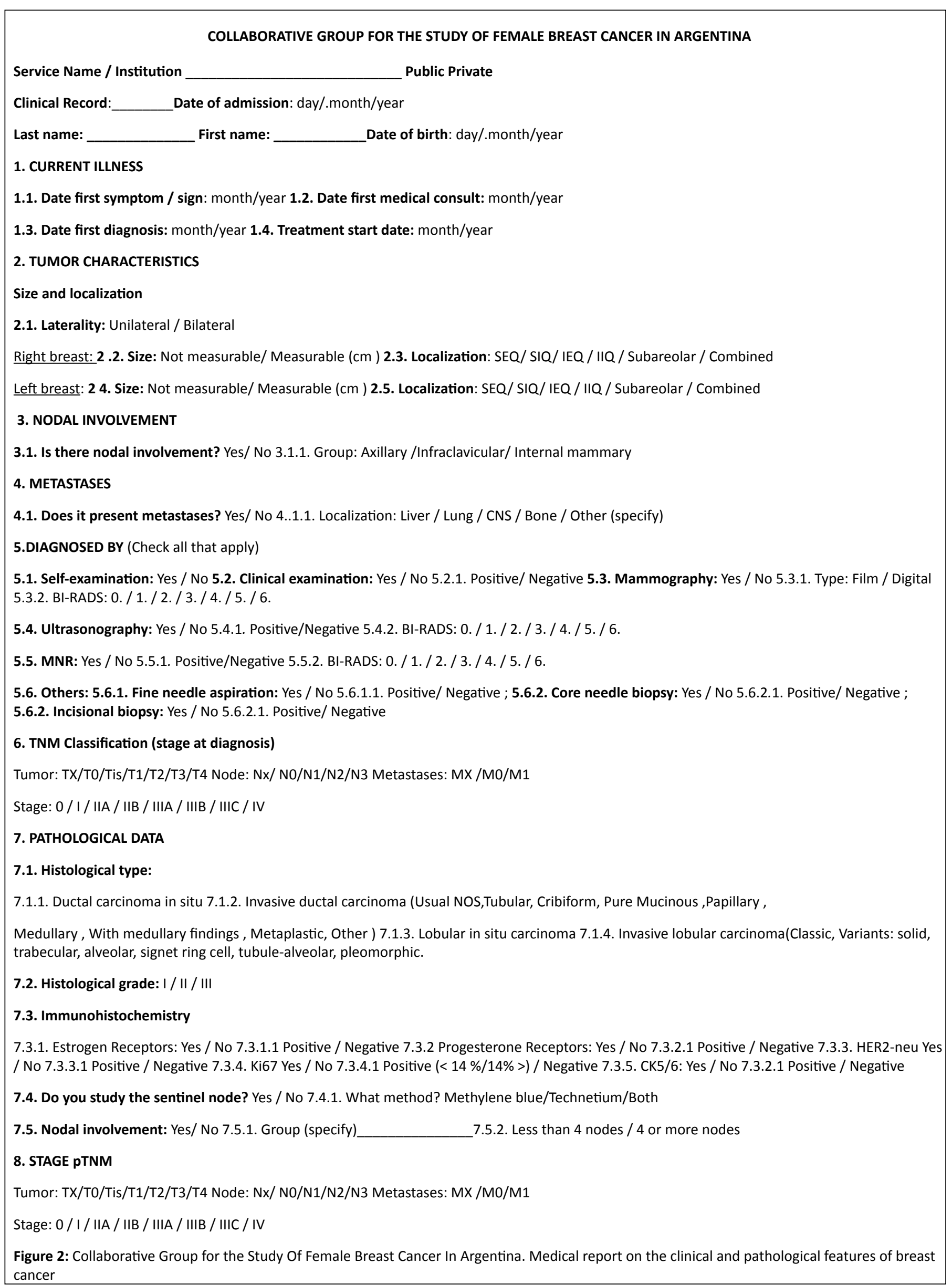


Citation: Roberto P. Meiss Kress MD Path, Roberto Chuit MD PhD, Jorge E. Novelli MD PhD, Eduardo Abalo MD PhD, Antonio Lorusso MD PhD, et al. (2016) Breast Cancer in Argentina: Analysis from a Collaborative Group for the Study of Female Breast Cancer. J Can Epi Treat 1(2): 5-16. doi: https://doi.org/10.24218/jcet.2016.10.

\section{INFORMED CONSENT}

Having attended this institution for the diagnosis and treatment of my breast pathology give my consent so that clinical and pathological data can be used, with strict confidentiality of my identity, in the research project: Collaborative Group for the Study of Female Breast Cancer in Argentina, and all other study of the same nature which may arise in the future.

I understand that the main purpose of the research is to improve prophylactic, diagnostic and treatment of this disease and all that beneficial to science. The institution complies with the ethical principles for medical research involving human beings as stated in the Declaration of Helsinki of the World Health Organization.

Figure 3: Collaborative Group for the Study of Female Breast Cancer in Argentina. Informed written consent from the patient

Table 1: Demographic characteristics of 1732 breast cancer patients

\begin{tabular}{|c|c|}
\hline Variables & Patients \\
\hline Age at diagnosis, median (range) & $59(23-92)$ \\
\hline \multicolumn{2}{|l|}{ Distribution by age-groups, $n(\%)$} \\
\hline$<30$ & $19(1,1)$ \\
\hline $30-34$ & $37(2,1)$ \\
\hline $35-39$ & $91(5,3)$ \\
\hline $40-44$ & $147(8,5)$ \\
\hline $45-49$ & $176(10,2)$ \\
\hline $50-54$ & $213(12,3)$ \\
\hline $55-59$ & $210(12,1)$ \\
\hline $60-64$ & $212(12,2)$ \\
\hline $65-69$ & $183(10,6)$ \\
\hline $70-74$ & $155(8,9)$ \\
\hline $75-79$ & $126(7,3)$ \\
\hline 80 and more & $149(8,6)$ \\
\hline Unknown & $14(0,8)$ \\
\hline Total & $1732(100)$ \\
\hline \multicolumn{2}{|l|}{ Education level attained, $\mathrm{n}(\%)$} \\
\hline None & $16(0,9)$ \\
\hline Primary uncompleted & $154(8,8)$ \\
\hline Primary completed & $298(17,2)$ \\
\hline Secondary uncompleted & $227(13,1)$ \\
\hline Secondary completed & $355(20,5)$ \\
\hline Tertiary/University uncompleted & $130(7,5)$ \\
\hline Tertiary/University completed & $420(24,2)$ \\
\hline Unknown & $133(7,7)$ \\
\hline \multicolumn{2}{|l|}{ Patient health coverage, $n(\%)$} \\
\hline Public health & $305(17,6)$ \\
\hline Pre-paid medicine & $288(16,6)$ \\
\hline Mutual health societies & $40(2,3)$ \\
\hline Social security & $1042(60,2)$ \\
\hline Unknown & $57(3,3)$ \\
\hline
\end{tabular}

shows an average of 13 years, a median of 13 years, a mode of 13 years, a standard deviation of 2 years and a range from a minimum of 9 years to a maximum of 21 years. The group with the highest percentage $(40,6 \%)$ of cases corresponded to 13 and 14 years (Table 2 ).

The data about menstruation is available in $94,6 \%$ of patients; 72 , $3 \%$ of patients were menopausal at the time of diagnosis. The age
Table 2: Gynecological and reproductive history of 1732 breast cancer patients

\begin{tabular}{|c|c|}
\hline Variables & Patients \\
\hline \multicolumn{2}{|l|}{ Body mass index, $\mathrm{n}(\%)$} \\
\hline Less 24.9 & $555(32,0)$ \\
\hline $25-29.9$ & $686(39,6)$ \\
\hline 30 or more & $313(18,1)$ \\
\hline Unknown & $178(10,3)$ \\
\hline \multicolumn{2}{|l|}{ Menopausal status } \\
\hline Age at menarche (median, range) & $13(9-21)$ \\
\hline Premenopausal status, n (\%) & $396(22,9)$ \\
\hline Postmenopausal status, n (\%) & $1752(72,3)$ \\
\hline Age at menopause (median, range) & $49(21-64)$ \\
\hline Hormone replacement therapy (HRT) use (yes), n (\%) & $165(9,5)$ \\
\hline Duration of using the HRT (years) (median, range) & $3(1-24)$ \\
\hline \multicolumn{2}{|l|}{ Reproductive history } \\
\hline Ever full-term pregnancy (yes), n (\%) & $1387(80,9)$ \\
\hline Age at first full-term pregnancy (median, range) & $24(14-46)$ \\
\hline Age $\geq 30$ years at first full-term pregnancy, $\mathrm{n}(\%)$ & $161(11,6)$ \\
\hline $\begin{array}{l}\text { Time between menarche and first pregnancy (years) } \\
\text { (median, range) }\end{array}$ & $12(0-33)$ \\
\hline \multicolumn{2}{|l|}{ Number of full-term pregnancies, $n$ (\%) } \\
\hline 1 child & $239(17,2)$ \\
\hline 2 children & $494(35,6)$ \\
\hline 3 children & $361(26,0)$ \\
\hline$\geq 4$ children & $293(21,2)$ \\
\hline Breastfeeding (yes), n (\%) & $1387(17,2)$ \\
\hline $\begin{array}{l}\text { Duration of breastfeeding, all pregnancies (months), } \\
\text { (median, range) }\end{array}$ & $6(1-24)$ \\
\hline Ever abortion (yes), n (\%) & $501(28,9)$ \\
\hline \multicolumn{2}{|l|}{ Number of abortions, $\mathrm{n}(\%)$} \\
\hline 1 & $281(56,1)$ \\
\hline 2 & $143(28,5)$ \\
\hline$\geq 3$ & $68(13,6)$ \\
\hline Unknown & $9(1,8)$ \\
\hline Oral contraceptive (OC) use (yes), n (\%) & $644(37,2)$ \\
\hline
\end{tabular}

of menopause has a median of 49 years (range 21-64) (Table 2). Only $9,5 \%$ of the studied women has a history of use of hormone replacement therapy (data available for $92,4 \%$ of cases); length of use, in most cases $(69,1 \%)$, was from 1 to 5 years with a median of 3 (range 1-24) years (Table 2). 
Citation: Roberto P. Meiss Kress MD Path, Roberto Chuit MD PhD, Jorge E. Novelli MD PhD, Eduardo Abalo MD PhD, Antonio Lorusso MD PhD, et al. (2016) Breast Cancer in Argentina: Analysis from a Collaborative Group for the Study of Female Breast Cancer. J Can Epi Treat 1(2): 5-16. doi: https://doi.org/10.24218/jcet.2016.10.

About $80,9 \%$ of patients report having had a full-term pregnancy (a $100 \%$ of data available). The most frequent number of children (data available for a $96 \%$ of cases) is 2 children $(35,6 \%)$ followed by the group of 3 children with $26,0 \%$, (Table 2 ). The age of women at birth of first child (a 93\% of data available) shows an average of 24 years, median 24 years, a mode of 25 years, a standard deviation of 5 years and a range from a minimum of 14 years to a maximum of 46 years. The group with the highest percentage of children corresponds to 21-25 years old patients $(34,6 \%)$. A total of $11,6 \%$ were primiparous patients older than 30 years (Table 2 ). Time between menarche and first pregnancy shows a median of 12 (range: 0 -33) years (Table 2). All patients with children $(80.9 \%)$ reported having breastfed; the median duration of breastfeeding (a $76 \%$ of data available) for the total number of children was 6 months, range 1-24 months (Table 2). Oral contraceptives were used by $37,2 \%$ of patients with a median duration of 3 (range 2-6) years. Nulliparous women accounted for $19,1 \%$ of the cases studied. History of abortion and the number of it (a data available for $80 \%$ of cases) was present

Table 3: Health history of 1732 breast cancer patients

\begin{tabular}{|c|c|}
\hline Variables & Patients \\
\hline History of personal breast pathology, $\mathrm{n}(\%)$ & 535 (30.9) \\
\hline Mammary dysplasia, n (\%) & $227(13.1)$ \\
\hline Atypical hyperplasia and carcinoma "in situ", n (\%) & $36(2.1)$ \\
\hline History of personal breast cancer (yes), $n(\%)$ & $170(9.8)$ \\
\hline History of personal non-breast cancer (yes), $n$ (\%) & $57(3,2)$ \\
\hline \multicolumn{2}{|l|}{ Localization of the personal non-breast cancer. } \\
\hline Cervix uteri, n (\%) & $17(29,8)$ \\
\hline Colon-rectum, n (\%) & $6(10,5)$ \\
\hline Lung, n (\%) & $2(3,5)$ \\
\hline Ovary, n (\%) & $1(1,8)$ \\
\hline Other NOS (not otherwise specified) , n (\%) & $27(47,4)$ \\
\hline Family history of breast cancer (yes), $n(\%)$ & $483(27,9)$ \\
\hline \multicolumn{2}{|l|}{ Kinship degree, family history of breast cancer } \\
\hline Mother, n (\%) & $193(36,3)$ \\
\hline Sister, $\mathrm{n}(\%)$ & $124(23,4)$ \\
\hline Aunt/Cousin, n (\%) & $207(39,0)$ \\
\hline Daughter, n (\%) & $1(0,2)$ \\
\hline Family history of non-breast cancer (yes), n (\%) & $411(23,7)$ \\
\hline \multicolumn{2}{|l|}{ Kinship degree, family history of non-breast cancer } \\
\hline Father/Mother, $\mathrm{n}(\%)$ & $253(57,9)$ \\
\hline Brother/Sister, n (\%) & $88(20,1)$ \\
\hline Uncle/Aunt; n (\%) & $96(22,0)$ \\
\hline \multicolumn{2}{|l|}{ Localization of the familiar non-breast cancer. } \\
\hline Lung, n (\%) & $80(17,8)$ \\
\hline Colon-rectum, n (\%) & $79(17,6)$ \\
\hline Prostate, n (\%) & $65(14,4)$ \\
\hline Pancreas, n (\%) & $37(8,2)$ \\
\hline Ovary, n (\%) & $28(6,2)$ \\
\hline Other NOS (not otherwise specified), n (\%) & $56(12,4)$ \\
\hline
\end{tabular}

in $28.9 \%$ of the cases with $84,6 \%$ of these cases for no more than two occasions (Table 2).

\section{Health history}

The BMI was recorded in $89,1 \%$ of cases; data showed a $39,6 \%$ of patients with overweight and $18.1 \%$ with obesity (Table 2 ).

The diagnosis of benign breast conditions (dysplasia) (a data available $94,3 \%$ of cases) was present in $13,1 \%$ of cases. Conditions such as atypical hyperplasia and carcinoma "in situ" (data available for $93, .4 \%$ of cases) were present in $1,7 \%$ of cases.

Table 4: Clinical characteristic of 1732 breast cancer tumors

\begin{tabular}{|c|c|}
\hline Variables & Tumors \\
\hline \multicolumn{2}{|l|}{ Localization } \\
\hline Unilateral, n (\%): & $1679(96,9)$ \\
\hline Bilateral, n (\%): & $53(3,1)$ \\
\hline Size(cm), median (range): & $2,0(0,01-15,0)$ \\
\hline \multicolumn{2}{|c|}{ Distribution by size-groups $(\mathrm{cm}), \mathrm{n}(\%)$ : } \\
\hline$<0.5$ & $71(4,1)$ \\
\hline $0.6-0.9$ & $61(3,5)$ \\
\hline $1.0-1.9$ & $400(23,1)$ \\
\hline $2.0-2.9$ & $351(20,3)$ \\
\hline $3.0-3.9$ & $208(12,0)$ \\
\hline $4.0-4.9$ & $145(8,4)$ \\
\hline$>5.0$ & $231(13,3)$ \\
\hline Unknown & $265(15,3)$ \\
\hline Nodal involvement (yes), $\mathrm{n}(\%)$ & $466(26,9)$ \\
\hline \multicolumn{2}{|c|}{ Nodal group committed ${ }^{(a)}, \mathrm{n}(\%)$ (a) There is commitment to more than one group } \\
\hline Axillary & $436(92,4)$ \\
\hline Infra-axillary & $5(1,1)$ \\
\hline Internal mammary & $2(0,4)$ \\
\hline Unknown & $29(6,1)$ \\
\hline Distal metastasis (yes), $\mathrm{n}(\%)$ & $43(2,3)$ \\
\hline \multicolumn{2}{|c|}{ Site of metastasis ${ }^{(\mathrm{a})}, \mathrm{n}(\%)^{(\mathrm{a})}$ Metastasis exist in more than one site } \\
\hline Bone & $18(32,7)$ \\
\hline Lung & $14(25,5)$ \\
\hline Liver & $12(21,8)$ \\
\hline CNS & $4(7,3)$ \\
\hline Other & $4(7,3)$ \\
\hline Unknown & $3(5,5)$ \\
\hline \multicolumn{2}{|l|}{ TNM clinical stages, $\mathrm{n}(\%)$} \\
\hline 0 & $162(9,4)$ \\
\hline I & $598(34,5)$ \\
\hline Ila & $452(26,1)$ \\
\hline $\mathrm{IIb}$ & $179(10,9)$ \\
\hline IIla & $131(7,6)$ \\
\hline IIIb & $58(3,3)$ \\
\hline IIIC & $11(0,6)$ \\
\hline IV & $41(2,4)$ \\
\hline Unknown & $100(5,8)$ \\
\hline
\end{tabular}


Citation: Roberto P. Meiss Kress MD Path, Roberto Chuit MD PhD, Jorge E. Novelli MD PhD, Eduardo Abalo MD PhD, Antonio Lorusso MD PhD, et al. (2016) Breast Cancer in Argentina: Analysis from a Collaborative Group for the Study of Female Breast Cancer. J Can Epi Treat 1(2): 5-16. doi: https://doi.org/10.24218/jcet.2016.10.

A previous history of breast cancer in patients (a data for $94,0 \%$ of cases) was present in of $9,8 \%$ of cases (Table 3 ).

A personal history of non-breast cancer is present in 57 cases (3, $3 \%) ; 56$ patients with a family history in one location and one patient in two (cervical and colon and rectum). A history of a cervical cancer is the most common $(29,8 \%)$ followed by the colon and rectum $(10,5 \%)$. Other non-specified cancers $(47,4 \%)$ are grouped in the Other NOS (not otherwise specified) category (Table 3).

The $27,9 \%$ of cases have a family history of breast cancer. As for family members affected aunt and cousin with $39,0 \%$ of cases, followed by the mother in $36,3 \%$ sister with $23,4 \%$ of cases; in 9 , $01 \%$ of cases this family history is associated to more than one of the members (Table 3).

A family history of non-breast cancer is found in $23,7 \%$ of cases. In order of frequency, there were $17,8 \%$ cases of lung cancer, 17 , $6 \%$ cases of colorectal cancer and $14,4 \%$ of prostate cancer (Table 3 ). The family member affected involves, mainly, the father or mother with $57,9 \%$ of cases; in $6,3 \%$ of cases this family history is associated to more than one member (Table 3 ).

\section{Clinical characteristics}

The tumor's locations in the breast (100\% of data available) show a slight predominance in the right breast and the upper outer quadrant. In 3, $1 \%$ patients the tumors are located in both breasts at the time of diagnosis (bilateral synchronous forms) (Table 4).

Tumor size ( $84,7 \%$ of data available) shows an average of 2,79 $\mathrm{cm}$; a median $2,00 \mathrm{~cm}$; a standard deviation of $2,03 \mathrm{~cm}$ and ranges from a 0,01 to a maximum of $15,00 \mathrm{~cm}$. A total of $43,4 \%$ of cases are between 1 and $3 \mathrm{~cm}$ long and 7,\% cases were tumors smaller than $1 \mathrm{~cm}$. It is noteworthy that there are 13, 3\% of tumors of 5 $\mathrm{cm}$ or more at time of diagnosis (Table 4).

In $26,9 \%$ of cases there was nodal involvement $(93,8 \%$ of data available); most of them $(92,4 \%)$ were the axillary nodes (Table 4$)$.

About 2, 5\% of patients had metastases at the time of clinical diagnosis (94, $5 \%$ of data available). The distribution of metastases were in bone $(32,7 \%)$, lung $(25,5 \%)$, liver $(21,8 \%)$ and CNS (16\%) (Table 4).

Clinical staging (94, 2\% of data available) showed 9, $4 \%$ of Stage 0 . The most frequent stage was Stage I with $34,5 \%$ of cases followed by stage IIA with $26,1 \%$ and from then onwards there are decreasing amounts in the other stages to reach $0,6 \%$ in stage IIIC. In stage IV a peak of $2,4 \%$ of cases is observed (Table 4 ).

\section{Histological characteristics}

In the histological diagnosis $(91,1 \%$ of data available) invasive forms predominate $(80,8 \%)$ over non-infiltrative ones $(10,9 \%)$. In both, noninvasive and invasive forms, prevail the subtypes of ductal origin with $97,11 \%$ and $87 \% \%$ of cases respectively (Table 5.). The diagnosis of invasive ductal carcinoma variants shows that NOS subtype, alone or in combination with others, is the most frequent $(55,6 \%)$. In lobular infiltrating carcinoma the classical variants are the most frequent $(51,8 \%)$. Histologic grade carcinomas Grade II predominates (54, 4\%). (Table 5).

Hormone receptor (HR) status was determined by immunohistochemistry in $83,1 \%$ of all cases for estrogen and $86,3 \%$ for progesterone; Her2-neu status was also available in
Table 5: Histological characteristics of 1732 breast cancer tumors

\begin{tabular}{|c|c|}
\hline Variables & Tumors \\
\hline \multicolumn{2}{|l|}{ Histopathology: } \\
\hline Non-infiltrative, (n, \%) & 207 (10.9) \\
\hline Lobular & $6(2.9)$ \\
\hline Ductal & $201(97,1)$ \\
\hline Infiltrative, (n, \%) & $1521(80.9)$ \\
\hline Lobular & $198(13,0)$ \\
\hline Ductal & $1323(87,0)$ \\
\hline Unknown & $154(8,2)$ \\
\hline \multicolumn{2}{|l|}{ Histological grade, $n$ (\%) } \\
\hline I & $243(14,0)$ \\
\hline II & $750(43,3)$ \\
\hline III & $499(28,8)$ \\
\hline Unknown & $240(13,9)$ \\
\hline \multicolumn{2}{|c|}{ Immunohistochemistry (cases performed), n (\%) } \\
\hline Estrogen receptors & $1498(86,5)$ \\
\hline Progesterone receptors & $1495(86,3)$ \\
\hline Her2-neu receptors & $1427(82,4)$ \\
\hline Ki 67 & $824(47,6)$ \\
\hline CK 5-6 & $33(1,9)$ \\
\hline \multicolumn{2}{|l|}{ Molecular profile (IHC), n (\%) } \\
\hline Estrogen (+); Progesterone (+); Her2-neu (-) & $983(69,5)$ \\
\hline Estrogen (-); Progesterone (-); Her2-neu (+) & $84(5,9)$ \\
\hline Triple positive & $106(7,5)$ \\
\hline Triple-negative & $141(10,0)$ \\
\hline Other & $101(7,1)$ \\
\hline \multicolumn{2}{|l|}{ TNM pathological stages, n (\%) } \\
\hline 0 & $124(7,2)$ \\
\hline 1 & $603(34,8)$ \\
\hline Ila & $386(22,3)$ \\
\hline $\mathrm{Ilb}$ & $204(11,8)$ \\
\hline IIla & $144(8,3)$ \\
\hline IIIb & $61(3,5)$ \\
\hline IIIC & $35(2,0)$ \\
\hline IV & $51(2,9)$ \\
\hline Unknown & $124(7,2)$ \\
\hline Total & $1732(100)$ \\
\hline
\end{tabular}

$82,4 \%$ of all cases. For cases with data available on ER, PR, and HER2 (1415 case patients), we defined five tumor subtypes with the following results : ER (+)/ PR (+)/ Her2-neu (-), 69,5\% ; ER (-)/ PR (-)/ Her2-neu (+), 5, 9\% ;ER (+)/ PR (+)/ Her2-neu (+) (Triple-positive), 7,5\% ; ER (-)/ PR (-)/ Her2-neu (-)(Triplenegative), $10,0 \%$ and others $7,1 \%$ (Table 5 ) .

Pathologic staging (a 92, 8\% of data available) showed 7, $2 \%$ of Stage 0 a percentage lower than in clinical stage $0(9,4 \%)$. As in clinical TNM in pathological TNM the most frequent stages were I and IIA with $34,8 \%$ and $22,3 \%$ respectively with decreasing amounts in the others stages until the $2.0 \%$ in stage IIIC. As in 
Citation: Roberto P. Meiss Kress MD Path, Roberto Chuit MD PhD, Jorge E. Novelli MD PhD, Eduardo Abalo MD PhD, Antonio Lorusso MD PhD, et al. (2016) Breast Cancer in Argentina: Analysis from a Collaborative Group for the Study of Female Breast Cancer. J Can Epi Treat 1(2): 5-16. doi: https://doi.org/10.24218/jcet.2016.10.

cTNM in stage IV a peak of 2, $9 \%$ cases are observed (Table 5).

\section{Discussion}

As it is the case in developed countries, $\mathrm{BC}$ is the most common female cancer in Argentina [1]. BC incidence and mortality have been increasing steadily in South America and especially in Argentina during the past 25-30 years [10,11]. Argentina, together with Uruguay, one of the neighbor countries, constitutes a cluster of women with the highest incidence rates for BC, not only in South America but also in all of Latin America $[1,10]$. These strikingly high incidence rates of BC in women in these two countries have already been identified as exceptional for the region 30 years ago [11]. Despite the fact that the World Bank indices ranks Argentina in the group of "less developed" countries and describes it as "medium human development" the incidence rates and mortality for women with BC are not consistent with those observed in countries with similar characteristics of development [4]; in contrast, our rates are similar to that of most developed countries, with a striking similarity to certain countries in Europe [10]. Taking all this into account, we intended to study the presentation features of new BC cases in women of our country in order to describe the clinicalepidemiological characteristics of presentation and compare our results with those published in the literature for Latin American countries and for those extra-regional countries with incidence rates similar to ours in an attempt to explain the high incidence rates observed above all estimated rates for this country.

Argentina is a large country with an extension of over 2, 8 million square $\mathrm{km}$. According to the 2010 census, the total population was $40,117,096$ inhabitants. Its population is mainly urban (90\%) and highly concentrated: $46 \%$ live in the capital city and in the province of Buenos Aires. Of the total number, 20,593,330 are women $(51 \%)$ and $48.5 \%$ of them are over 25 years old. The distribution of our cases with a predominance of those from both the city and the province of Buenos Aires $(43,4 \%)$ is similar to the population distribution according to the last census [7], which indicates that the territorial distribution of breast cancer is mainly due to factors related to population density and not to other geographical variables.

Aging is the main risk factor for BC. Demographic changes in Latin America lead to an epidemiological transition, transforming the age structure of society into an ageing one. Today, $11,8 \%$ of Argentina's female population is above 65 years of age, being one of the oldest female populations in Latin America [7].The presentation profile of BC in the series studied shows a predominant population of women over 55 years of age (median of 59). Uncommon below 30 years of age $(1,1 \%), \mathrm{BC}$ doubles the cases in 30-34 year-old women (2,1\%), keeping up this increase rate in 35-39 year-old (5,3\%) and 40-44 year-old $(8,5 \%)$ age groups. Up until this age group, the increase of cases is almost constant, every five-year periods; afterwards, the trend tends to stabilize between the 45-49 and the 65-69 year-old age groups. Considering the age limit for systematic mammographic screening recommended $[8,9]$ we have observed that $8,5 \%$ of our BC cases appear in women under 40 and $18,7 \%$ more cases are added between 40 and 50 years of age. These percentages are not consistent with those outlined for developing countries, particularly those of Latin America, where there is predominance of young patients and with a proportion of women under 40 that varies between countries from $8,2 \%$ to $14 \%$, our percentage $(8,5 \%)$ being closer to lower values [10]. On the contrary, this profile is similar to that observed in developed countries [11].

The country has a well-developed public health system that coexists with a social security system and a private sector; approximately $41 \%$ of the population lacks any form of health insurance so they are managed by the public health sector. The relationship between socioeconomic status and risk of BC is well established, with women with a higher socioeconomic background at also a higher risk. By contrast those cases in patients with lower socioeconomic background occur in more advanced stages [12]. This relationship is most likely indirectly related to lifestyle differences. In our study, the socioeconomic level was indirectly evaluated through education level and the health coverage system of the patient. $52,2 \%$ of the patients had a high school or higher education diploma, $24 \%$ of them with complete university studies, while in the last 2010 census the percentage of women over 25 with that level of studies was $17.8 \%$. In Argentina, a minimum benefit of health services is guaranteed by law to the whole population, so all $\mathrm{BC}$ patients have free access to oncology treatment. $79,1 \%$ of patients were covered either by the social security or by prepaid medical care. Both variables point to a woman of medium to high cultural and economic levels as described in populations of developed countries [13].

The most known major risk factors for $\mathrm{BC}$ are environmental and mainly hormonal. The hypothesis that hormonal exposure that occurs between menarche and menopause and more recently in the time between menarche and age at first pregnancy is especially important in determining subsequent risk of $\mathrm{BC}$ is supported by several lines of evidence $[14,15]$. Although the median age of menarche was 13 years of age and the highest percentage was in the group of 13 and $14,43,3 \%$ of patients had menarche at 12 or younger. These values are consistent with other series [16] and indicative, to some extent, of a cohort of women with a relative early menarche onset.

It is known that women who undergo menopause before age 30 have a reduction in $\mathrm{BC}$ risk when compared with women who undergo menopause after age $55[16,17]$ Data from our study show a population of menopausal women (72.3\%) with a median age of cessation of menses of 49 with a broad range between 21 and 64. The time of exposure to hormones, when calculated using the difference between the median age at menarche and menopause, shows a value of 36 years for the population under study. Median age between the age of the last menstruation and the age of onset of BC shows a difference of 10 years, 49 and 59 years respectively. Our finding of a dominant postmenopausal population does not match one debated theory about a higher incidence of premenopausal breast cancer in less developed countries [18].

Only $9,5 \%$ of patients had an HRT and most of them $(69,1 \%)$ for less than 5 years. This low rate of use and the short length of the treatment may be due to the well-known complications [19] that led to the contraindication of its use after the 2002 publication of the Women's Health Initiative randomized trial results [20]. It was at that time when this cohort of women with $\mathrm{BC}$ cancer went into menopause. 
Citation: Roberto P. Meiss Kress MD Path, Roberto Chuit MD PhD, Jorge E. Novelli MD PhD, Eduardo Abalo MD PhD, Antonio Lorusso MD PhD, et al. (2016) Breast Cancer in Argentina: Analysis from a Collaborative Group for the Study of Female Breast Cancer. J Can Epi Treat 1(2): 5-16. doi: https://doi.org/10.24218/jcet.2016.10.

While low and delayed parity are known risk factors for the disease, lactation appears to play an important role in protecting women from BC [21]. There are changes in Argentinian women's lifestyles with a decline in the fertility rate. According to the last census, the average number of children was 2 and the average age at first birth was 24 years, both data similar to those observed in the patients in our series. A first full-term pregnancy before age 21 appears to have a protective effect against BC and in our series only $20,9 \%$ of the patients were under that age at the time of first delivery. On the other hand, a late (over 30 years of age) first fullterm pregnancy $(11,6 \%$ of the patients) and null parity, $19,1 \%$ of our cases versus the $11 \%$ of the female population over 25 years old according to the last census [7] , may be associated with a higher risk [22]. None of these values are particularly high when compared with those mentioned in other publications $[23,24]$ .The use of oral contraceptives linked to increased risk of breast cancer [25], was present in only in 37, $2 \%$ cases and for no more than 3 years not being thus a significant risk factor in this series.

The existence of a history of interrupted pregnancies and the amount of these were considered, particularly in the past, as possible risk factors for breast cancer [26]. With only $28,9 \%$ of patients with this history and in most cases (84.6\%) in not more than two occasions, these values do not appear to be significant and even less so if this is not currently considered a relevant risk factor [27]. The practice of breastfeeding and a longer duration of it are considered as protective factors of the mammary gland, thereby reducing the lifetime risk for developing a cancer. Although $100 \%$ of the parous women (1387) in this series reported having practiced breastfeeding, quite a high percentage if compared with other series [28] the average length of lactation - taking into account all of the patient's breastfed children - was only 6 months with a range between 0 and 24 . This length of time would be insufficient to exert the debatable protective effect attributable to breastfeeding duration $[28,29]$ and it is within the shortest time recommended by medical organizations [30].

For years the increase in BMI was related to the risk of developing BC primarily in postmenopausal women [31]. More than half of our patients were either overweight $(39,6 \%)$ or obese $(18,1 \%)$ at the time of diagnosis. These data on changes in BMI are relevant as risk factor because they come from a population of mainly menopausal patients $(72,3 \%)$ at the time of diagnosis of $\mathrm{BC}$, as mentioned before.

The report of a history of a diagnosis of proliferative benign breast disease such as dysplasia, an entity with a low to moderate increased risk for the development of BC, was relative low $(13,1 \%$ in this study), taking in account that it is more frequent in the general population [32]. Conditions such as atypical hyperplasia and carcinoma "in situ", both more closely related to the development of subsequent invasive cancer [33], were reported in a low percentage $(1,7 \%)$. It should be noted that these records were collected by interrogation without histopathological confirmation. This could explain the observed differences with other series where the frequency is higher [34]. A more accurate history of personal BC is present in $9,8 \%$ of cases, similar to the frequency observed in other series [35]. Family history of cancer reflects not only the consequences of genetic susceptibilities but also of shared environment and common culture. The percentage of family BC in our series (27, 9\%) and its distribution according to degree of kinship is quite similar to that cited worldwide [36, 37]. A history of family non-breast cancer, although present in a high percentage of cases $(23,7 \%)$ in comparison with other series, shows no relevant data regarding types of cancers and frequencies thereof [38].

The main morphological characteristics, like size and location, show a striking fact: a rate of $3 \%$ of bilateral cases at time of diagnosis (synchronous forms). This is a high value compared to past and current series [39] and strikingly it is almost double the figure recorded in a previous work done by us [40]. Histologically, infiltrative ductal carcinomas are the most common $-76.3 \%$ of cases in this series - as noted throughout the literature $[41,42]$ while the percentage of infiltrative lobular carcinomas $-11.4 \%$ in our series - is quite similar to that reported in literature - almost $10 \%$ [43]. As for "in situ" forms, ductal carcinoma in situ (DCIS) has become a more frequent form after the introduction of screening mammography, representing up to $20 \%-25 \%$ of all breast malignancies in industrialized countries [44]. This is not what happens in our series, where DCIS only represents $11.6 \%$ of all cases. On the other hand, lobular carcinoma in situ (LCIS) constitutes only $0.34 \%$ of the total when literature indicates a frequency in otherwise benign biopsy specimens ranging from $0.5 \%$ to $3.8 \%$ [45]. These low percentages in our study may be due to the fact that these forms increase their diagnostic frequency when the mammogram is applied in screening programs and not only in sporadic screening or for diagnostic purposes. This is the picture in the detection of breast cancer in our country, similar to that mentioned for other countries in the region [46]. For breast cancer, histologic grade remains a prognostic factor despite changes in tumor size and number of positive lymph nodes [47]; it may be indirectly informative about tumor biology. With more than half the tumors (57\%) with grades 1 and 2, tumors in this series appear to be biologically less aggressive.

According to an expert survey in Latin America, contrary to the relatively low or non-adherence to routine mammography screening, post-diagnostic screening with hormone receptors and biologic marker determination is widely spread in the region [48]. Thus, in our series the study of hormone receptors was performed in more than $86 \%$ of cases and of Her2-neu in over $80 \%$. These rates of performance are among the highest according to the consulted bibliography [49]. The study of the proliferation index by the expression of ki-67 protein was performed in nearly $50 \%$ of cases. IHC expression of CK 5-6, used to differentiate luminal types A from B, was used in less than $2 \%$ of cases. Hormone receptors were studied by IHC in over $80 \%$ of cases, having in $1247(82,4 \%)$ of the total cases also the study of Her-2neu which allowed us to define molecular types. HR (+); Her2neu (-) is the most frequent and their percentage (close to $70 \%$ ) is similar to most of the series analyzed [50].In the remaining cases, subtype "triple-negative" (10\%) prevails, followed by the "triple-positive" (7,5\%). These subtypes with a special prognostic/predictive significance are present in similar proportions to those mentioned in other populations studied and are consistent with the distribution in series with predominance of postmenopausal patients $[49,50]$.

The stage at time of diagnosis affects the outcome and consequently the burden of the disease on societies. In our series, stages 0 and I take together correspond to $43,9 \%$ of cases. This percentage is 
Citation: Roberto P. Meiss Kress MD Path, Roberto Chuit MD PhD, Jorge E. Novelli MD PhD, Eduardo Abalo MD PhD, Antonio Lorusso MD PhD, et al. (2016) Breast Cancer in Argentina: Analysis from a Collaborative Group for the Study of Female Breast Cancer. J Can Epi Treat 1(2): 5-16. doi: https://doi.org/10.24218/jcet.2016.10.

much higher than that mentioned for stage I in some series from Latin American countries, where the incidence ranges between 9\% (Brazil, Peru and Mexico) and 40\% (Uruguay). Conversely in this series only $2,4 \%$ breast cancers were diagnosed with denovo distant metastases, at stage IV. This percentage is among the three lowest percentages reported in a total of 14 sets of breast cancer from countries in the region [51]. When comparing the stages of presentation in our series and those outlined in a series from a developed country like the United States [52], it is observed that in the latter, stages 0 and I predominate while in our series stages II and III $(48,5 \%)$ are the most frequent. The prevalence of early stages in developed countries may be due to a massive and continuous use of mammogram screening in these populations. On the contrary, in our population, although the use of mammography is known and applied, it is not massive and systematic [48]. In stage IV our percentage $(2.4 \%)$ is lower than that referred for more developed societies (6-7\%) [53] .This situation may reflect the presence of more aggressive tumors that debut with metastatic stages or, perhaps more likely, that the techniques used for staging BC are of higher sensitivity and specificity in developed societies.

\section{Conclusion}

In summary, the profile of BC cases studied shows mostly a population of postmenopausal women averaging 60 years of age. Recognized risk factors related to reproduction (menarche, age at menopause, parity and lactation) are present with values similar to those described in Western populations in developed countries. Personal and/or family history of breast cancer and other non-breast cancer rates are similar to those observed in developed and Western populations. Regarding histological types and molecular profiles of tumors, no significant differences are observed when compared to other populations worldwide. Given all the previously mentioned variables, we have a population that shows a "western and developed" profile. This profile may describe a population with high incidence rates for the region, although these rates are lower than those in more developed Western countries for this type of cancer [1].

It had been suggested that the geographic variation in $\mathrm{BC}$ incidence is due to differences between countries in known risk factors, especially reproductive ones $[54,55]$. Nevertheless, hypotheses which postulate that the known reproductive risk factors cannot completely explain the geographic variation in $\mathrm{BC}$ incidence have been listed [56-58]. In our country, the influence of predominantly European immigration - an element of extreme importance in population composition during the last centuryon the genetic and cultural background of the population should be also considered [59]. We believe that classic demographic and clinic-pathological factors must be fully integrated with the results of the new and ever more numerous investigations on population genomic profiles [60-62] in order to explain the high incidence rates observed in our country as compared to those observed in the region and among other developing countries [63-65].

\section{Acknowledgement}

Paula Meiss, Ariel Gualtieri, Marcelo Guruceaga and Natalia Gonçalves for their continued support in the development of this project.

\section{References}

1. Ferlay J, Soerjomataram I, Ervik M, Dikshit R, Eser S, Mathers C, et al. GLOBOCAN 2012 v1.0, Cancer Incidence and Mortality Worldwide: IARC CancerBase No. 11 [Internet]. Lyon, France: International Agency for Research on Cancer; 2013. Available from: http://globocan.iarc.fr, accessed on 13/11/2015

2. Bhikoo R, Srinivasa S, Yu TC, Moss D, Hill AG. Systematic review of breast cancer biology in developing countries (part 1): Africa, the middle East, eastern Europe, Mexico, the Caribbean and South America. Cancers (Basel). 2011; 3(2):2358-81. doi: 10.3390/ cancers3022358.

3. Forouzanfar $\mathrm{MH}$, Foreman $\mathrm{KJ}$, Delossantos $\mathrm{AM}$, Lozano $\mathrm{R}$, Lopez $A D$, Murray CJ, et al. Breast and cervical cancer in 187 countries between 1980 and 2010: a systematic analysis. Lancet 2011; 378(9801):1461-1484. doi:10.1016/S0140-6736(11)61351-2.

4. World Bank. World Development Indicators 2013, DC, 2013 [consulted Apr 2014]. Available from: http://data.worldbank.org/ data-catalog/world-developmentent-indicators/wdi-2013.04/2014

5. Edge SB, Byrd DR, Compton CC, Fritz AG, Greene FL, Trotti A, editors. AJCC cancer staging manual. 7th ed. New York: Springer; 2009. p. 419-60.

6. Lakhani S, Ellis I, Schnitt S, et al. WHO Classification of Tumours of the Breast. 4th. Lyon: IARC Press; 2012.

7. INDEC. Censo Nacional de Población, Familias y Viviendas 1970. Censo Nacional de Población y Viviendas 1980 y 1991. Censo Nacional de Población, Hogares y Viviendas 2001 y 2010. Argentina.

8. Mandelblatt JS, Cronin KA, Bailey S, Berry DA, de Koning HJ, Draisma $G$, et al. Effects of mammography screening under different screening schedules: model estimates of potential benefits and harms. Ann Intern Med. 2009; 151(10):738-47. doi: 10.1059/00034819-151-10-200911170-00010.

9. Oeffinger KC, Fontham ET, Etzioni R, Herzig A, Michaelson JS, Shih YC, et al. American Cancer Society. Breast Cancer Screening for Women at Average Risk: 2015 Guideline Update From the American Cancer Society. JAMA. 2015; 314(15):1599-614. doi: 10.1001/ jama.2015.12783.

10. Villarreal-Garza C, Aguila C, Magallanes-Hoyos MC, Mohar A, Bargalló $E$, Meneses $A$, et al. Breast cancer in young women in Latin America: an unmet, growing burden. Oncologist. 2013; 18(12):1298-306. doi: 10.1634/theoncologist.2013-0321.

11. Torre LA, Bray F, Siegel RL, Ferlay J, Lortet-Tieulent J, Jemal A. Global cancer statistics, 2012. CA Cancer J Clin. 2015; 65(2):87-108.

12. MacKinnon JA, Duncan RC, Huang Y. Detecting an association between socioeconomic status and late stage breast cancer using spatial analysis and area-based measures. Cancer Epidemiol Biomarkers Prev. 2007; 16(4):756-762.

13. Klassen AC, Smith KC. The enduring and evolving relationship between social class and breast cancer burden: a review of the literature. Cancer Epidemiol. 2011; 35(3):217-34. doi: 10.1016/j. canep.2011.02.009.

14. Albrektsen G, Heuch I, Thoresen S, Kvåle G. Clinical stage of breast cancer by parity, age at birth, and time since birth: a progressive effect of pregnancy hormones? Cancer Epidemiol Biomarkers Prev. 2006; 15(1):65-9.

15. Parent AS, Teilmann G, Juul A, Skakkebaek NE, Toppari J, Bourguignon JP. The timing of normal puberty and the age limits of sexual precocity: variations around the world, secular trends, and changes after migration. Endocr Rev. 2003; 24(5):668-93. 
Citation: Roberto P. Meiss Kress MD Path, Roberto Chuit MD PhD, Jorge E. Novelli MD PhD, Eduardo Abalo MD PhD, Antonio Lorusso MD PhD, et al. (2016) Breast Cancer in Argentina: Analysis from a Collaborative Group for the Study of Female Breast Cancer. J Can Epi Treat 1(2): 5-16. doi: https://doi.org/10.24218/jcet.2016.10.

16. Collaborative Group on Hormonal Factors in Breast Cancer Menarche, menopause, and breast cancer risk: individual participant meta-analysis, including 118964 women with breast cancer from 117 epidemiological studies. Lancet Oncol. 2012; 13(11):1141-51. doi: 10.1016/S1470-2045(12)70425-4.

17. Colditz GA, Rosner B. Cumulative risk of breast cancer to age 70 years according to risk factor status: data from the Nurses' Health Study. Am J Epidemiol. 2000; 152(10):950-64.

18. Ghiasvand R, Adami HO, Harirchi I, Akrami R, Zendehdel K. Higher incidence of premenopausal breast cancer in less developed countries; myth or truth? BMC Cancer. 2014; 14:343. doi: 10.1186/1471-2407-14-343.

19. Hou N, Hong S, Wang W, Olopade OI, Dignam JJ, Huo D. Hormone replacement therapy and breast cancer: heterogeneous risks by race, weight, and breast density. J Natl Cancer Inst. 2013; 105(18):1365-72. doi: 10.1093/jnci/djt207.

20. Rossouw JE, Anderson GL, Prentice RL, LaCroix AZ, Kooperberg C, Stefanick ML, et al. Risks and benefits of estrogen plus progestin in healthy postmenopausal women: principal results From the Women's Health Initiative randomized controlled trial. JAMA. 2002; 288(3):321-33.

21. Collaborative Group on Hormonal Factors in Breast Cancer. Breast cancer and breastfeeding: collaborative reanalysis of individual data from 47 epidemiological studies in 30 countries, including 50302 women with breast cancer and 96973 women without the disease. Lancet. 2002; 360(9328):187-95.

22. Reigstad MM, Larsen IK, Myklebust TÅ, Robsahm TE, Oldereid NB, Omland AK, et al. Risk of breast cancer following fertility treatment-a registry based cohort study of parous women in Norway. Int J Cancer. 2015; 136(5):1140-8. doi: 10.1002/ijc. 29069.

23. Kobayashi S, Sugiura $H$, Ando $Y$, Shiraki N, Yanagi T, Yamashita $H$, et al. Reproductive history and breast cancer risk. Breast Cancer. 2012; 19(4):302-8. doi: 10.1007/s12282-012-0384-8.

24. Work ME, John EM, Andrulis IL, Knight JA, Liao Y, Mulligan AM, et al. Reproductive risk factors and oestrogen /progesterone receptornegative breast cancer in the Breast Cancer Family Registry. Br J Cancer. 2014; 110(5):1367-77. doi: 10.1038/bjc.2013.807.

25. Rosenberg L, Zhang Y, Coogan PF, Strom BL, Palmer JR. A casecontrol study of oral contraceptive use and incident breast cancer Am J Epidemiol. 2009; 169(4):473-9. doi: 10.1093/aje/kwn360.

26. Brind J, Chinchilli VM, Severs WB, Summy-Long J. Induced abortion as an independent risk factor for breast cancer: a comprehensive review and meta-analysis. J Epidemiol Community Health. 1996; 50(5):481-96.

27. Beral V, Bull D, Doll R, Peto R, Reeves G; Collaborative Group on Hormonal Factors in Breast Cancer. Breast cancer and abortion: collaborative reanalysis of data from 53 epidemiological studies, including 83000 women with breast cancer from 16 countries. Lancet. 2004; 363(9414):1007-16.

28. Lee H, Li JY, Fan JH, Li J, Huang R, Zhang BN, et al. Risk factors for breast cancer among Chinese women: a 10-year nationwide multicenter cross-sectional study. J Epidemiol. 2014; 24(1):67-76.

29. ButtS, BorgquistS, AnagnostakiL,LandbergG, ManjerJ.Breastfeeding in relation to risk of different breast cancer characteristics. BMC Res Notes. 2014; 7:216. doi: 10.1186/1756-0500-7-216.
30. Haroon S, Das JK, Salam RA, Imdad A, Bhutta ZA. Breastfeeding promotion interventions and breastfeeding practices: a systematic review. BMC Public Health. 2013; 13 Suppl 3:S20. doi: 10.1186/14712458-13-S3-S20.

31. Gaudet MM, Carter BD, Patel AV, Teras LR, Jacobs EJ, Gapstur SM. Waist circumference, body mass index, and postmenopausal breast cancer incidence in the Cancer Prevention Study-II Nutrition Cohort. Cancer Causes Control. 2014; 25(6):737-45. doi: 10.1007/ s10552-014-0376-4.

32. Dyrstad SW, Yan Y, Fowler AM, Colditz GA. Breast cancer risk associated with benign breast disease: systematic review and meta-analysis. Breast Cancer Res Treat. 2015; 149(3):569-75. doi: 10.1007/s10549-014-3254-6.

33. Hartmann LC, Degnim AC, Santen RJ, Dupont WD, Ghosh K. Atypical hyperplasia of the breast--risk assessment and management options. N Engl J Med. 2015; 372(1):78-89. doi: 10.1056/ NEJMsr1407164.

34. To $T$, Wall $C$, Baines $C J$, Miller $A B$. Is carcinoma in situ a precursor lesion of invasive breast cancer? Int J Cancer. 2014; 135(7):164652. doi: 10.1002/ijc.28803.

35. Houssami N, Abraham LA, Kerlikowske K, Buist DS, Irwig L, Lee J, et al. Risk factors for second screen-detected or interval breast cancers in women with a personal history of breast cancer participating in mammography screening. Cancer Epidemiol Biomarkers Prev. 2013; 22(5):946-61. doi: 10.1158/1055-9965.EPI-12-1208-T.

36. Verkooijen HM, Chappuis PO, Rapiti E, Vlastos G, Fioretta G, Sarp $S$, et al. Impact of familial risk factors on management and survival of early-onset breast cancer: a population-based study. Br J Cancer. 2006; 94(2):231-8.

37. Martin LJ, Melnichouk O, Guo H, Chiarelli AM, Hislop TG, Yaffe MJ, et al. Family history, mammographic density, and risk of breast cancer. Cancer Epidemiol Biomarkers Prev. 2010; 19(2): 456463. doi: 10.1158/1055-9965.EPI-09-0881.

38. Turati F, Edefonti V, Bosetti C, Ferraroni M, Malvezzi M, Franceschi $\mathrm{S}$, et al. Family history of cancer and the risk of cancer: a network of case-control studies. Ann Oncol. 2013; 24(10):2651-6.

39. Rummel S, Hueman MT, Costantino N, Shriver CD, Ellsworth RE. Tumour location within the breast: Does tumour site have prognostic ability? Ecancermedicalscience. 2015; 9:552. doi: 10.3332/ecancer.2015.552.

40. Kelmendi de Ustarán J, Meiss RP. Primary synchronous bilateral breast cancer: epidemiological approach. Breast Cancer Res Treat. 1988; 12(3):311-4.

41. Howlader N, Noone AM, Krapcho M, Garshell J, Miller D, Altekruse SF, et al, editors. SEER Cancer Statistics Review, 1975-2011, National Cancer Institute. Bethesda, http://seer.cancer.gov/csr/1975_2011/, based on November 2013 SEER data submission, posted to the SEER web site, April 2014.

42. Anderson WF, Pfeiffer RM, Dores GM, Sherman ME. Comparison of age distribution patterns for different histopathologic types of breast carcinoma. Cancer Epidemiol Biomarkers Prev. 2006; 15(10):1899-90.

43. Dossus L, Benusiglio PR. Lobular breast cancer: incidence and genetic and non-genetic risk factors. Breast Cancer Res. 2015; 17:37. doi: 10.1186/s13058-015-0546-7. 
Citation: Roberto P. Meiss Kress MD Path, Roberto Chuit MD PhD, Jorge E. Novelli MD PhD, Eduardo Abalo MD PhD, Antonio Lorusso MD PhD, et al. (2016) Breast Cancer in Argentina: Analysis from a Collaborative Group for the Study of Female Breast Cancer. J Can Epi Treat 1(2): 5-16. doi: https://doi.org/10.24218/jcet.2016.10.

44. Lynge E, Ponti A, James T, Májek O, von Euler-Chelpin M, Anttila $A$, et al. Variation in detection of ductal carcinoma in situ during screening mammography: a survey within the International Cancer Screening Network. Eur J Cancer. 2014; 50(1):185-92. doi: 10.1016/j.ejca.2013.08.013.

45. Eheman CR, Shaw KM, Ryerson AB, Miller JW, Ajani UA, White MC. The changing incidence of in situ and invasive ductal and lobular breast carcinomas: United States, 1999-2004. Cancer Epidemiol Biomarkers Prev. 2009; 18(6):1763-9. doi: 10.1158/1055-9965.EPI08-1082.

46. Reyes-Ortiz CA, Freeman JL, Peláez M, Markides KS, Goodwin JS. Mammography use among older women of seven Latin American and Caribbean cities. Prev Med. 2006; 42(5):375-80.

47. Schwartz AM, Henson DE, Chen D, Rajamarthandan S. Histologic grade remains a prognostic factor for breast cancer regardless of the number of positive lymph nodes and tumor size: a study of 161708 cases of breast cancer from the SEER Program. Arch Pathol Lab Med. 2014; 138(8):1048-52. doi: 10.5858/arpa.2013-0435-OA.

48. Cazap E, Buzaid AC, Garbino C, de la Garza J, Orlandi FJ, Schwartsmann G, et al. Breast cancer in Latin America: results of the Latin American and Caribbean Society of Medical Oncology/ Breast Cancer Research Foundation expert survey. Cancer. 2008; 113(8 Suppl):2359-65. doi: 10.1002/cncr.23834.

49. Borgquist S, Zhou W, Jirström K, Amini RM, Sollie T, Sørlie T, et al. The prognostic role of HER2 expression in ductal breast carcinoma in situ (DCIS); a population-based cohort study. BMC Cancer. 2015; 15:468. doi: 10.1186/s12885-015-1479-3.

50. Bhargava R, Striebel J, Beriwal S, Flickinger JC, Onisko A, Ahrendt $\mathrm{G}$, et al. Prevalence, morphologic features and proliferation indices of breast carcinoma molecular classes using immunohistochemical surrogate markers. Int J Clin Exp Pathol. 2009; 2(5):444-55.

51. Justo N, Wilking N, Jönsson B, Luciani S, Cazap E. A review of breast cancer care and outcomes in Latin America. Oncologist. 2013; 18(3):248-56. doi: 10.1634/theoncologist.2012-0373.

52. Althuis MD, Dozier JM, Anderson WF, Devesa SS, Brinton LA. Global trends in breast cancer incidence and mortality 1973-1997. Int J Epidemiol. 2005; 34(2):405-12.
53. Unger-Saldaña K. Challenges to the early diagnosis and treatment of breast cancer in developing countries. World J Clin Oncol. 2014; 5(3):465-77. doi: 10.5306/wjco.v5.i3.465.

54. Colditz GA. Epidemiology and prevention of breast cancer. Cancer Epidemiol Biomarkers Prev. 2005; 14(4):768-772.

55. Beral V, Banks $E$, Reeves $G$. Evidence from randomised trials on the long-term effects of hormone replacement therapy. Lancet. 2002; 360(9337):942-4.

56. Colditz GA. Epidemiology and prevention of breast cancer. Cancer Epidemiol Biomarkers Prev. 2005; 14(4):768-72.

57. MacMahon B. Epidemiology and the causes of breast cancer. Int J Cancer. 2006; 118(10):2373-8.

58. Hoover RN. That recognized risk factors can explain past and present international differences in breast cancer incidence: misconceptions 5. Br J Cancer. 2012; 107(3):408-410. doi: 10.1038/ bjc.2012.134.

59. Pharoah PD, Antoniou AC, Easton DF, Ponder BA. Polygenes, risk prediction, and targeted prevention of breast cancer. N Engl J Med. 2008; 358(26):2796-803. doi: 10.1056/NEJMsa0708739.

60. Pashayan N, Pharoah P. Population-based screening in the era of genomics. Per Med. 2012; 9(4):451-455.

61. Chowdhury S, Dent T, Pashayan N, Hall A, Lyratzopoulos G, Hallowell $\mathrm{N}$, et al. Incorporating genomics into breast and prostate cancer screening: assessing the implications. Genet Med. 2013; 15(6):42332. doi: $10.1038 /$ gim.2012.167.

62. Slattery ML, Herrick JS, Torres-Mejia G, John EM, Giuliano AR, Hines LM, et al. Genetic variants in interleukin genes are associated with breast cancer risk and survival in a genetically admixed population: the Breast Cancer Health Disparities Study. Carcinogenesis. 2014; 35(8):1750-9. doi: 10.1093/carcin/bgu078.

63. Guan YP, Yang XX, Yao GY, Qiu F, Chen J, Chen LJ, et al. Breast cancer association studies in a Han Chinese population using 10 Europeanancestry-associated breast cancer susceptibility SNPs. Asian Pac J Cancer Prev. 2014; 15(1):85-91.

64. Bonilla C, Bertoni B, Hidalgo PC, Artagaveytia N, Ackermann E, Barreto I, et al. Breast cancer risk and genetic ancestry: a casecontrol study in Uruguay. BMC Womens Health. 2015; 15:11. doi: 10.1186/s12905-015-0171-8. 